\title{
Multikulturalita Ruské federace a její reflexe ve školním vzdělávání
}

\author{
Věra Ježková \\ Univerzita Karlova, Pedagogická fakulta, Ústav výzkumu a rozvoje vzdělávání
}

Redakci zasláno 24. 4. 2012 / upravená verze obdržena 16. 8. 2012 / k uveřejnění přijato 21. 8. 2012

\begin{abstract}
Abstrakt: Ruská federace je značně multikulturní země. Tato skutečnost se projevuje také ve škole. Předmětem studie jsou dvě hlavní oblasti: řešení národnostní otázky a jazyková politika Ruské federace, a to na úrovni celé společnosti a na úrovni školního vzdělávání. Ve shrnutí je stručně porovnána situace v Ruské federaci se situací v dříve sledovaných zemích: Německu, Velké Británii, Švédsku (a České republice).
\end{abstract}

Klíčová slova: národnostní politika, jazyková politika, legislativa, kurikulum, Ruská federace

\section{1 Úvod}

Následující stat' volně navazuje na studii Multikulturalita Německa, Velké Británie, Švédska a České republiky a opatření vzdělávací politiky pro školní vzdělávání, uveřejněnou v časopise Orbis scholae 3/2010 (Ježková, 2010). V rámci studia problematiky školního vzdělávání ve vybraných zemích jsme se začali zabývat nově školním vzděláváním v Ruské federaci. Přehledový článek Reforma školního vzdělávání v Rusku je uveřejněn v časopise Orbis scholae 1/2012 (Ježková, 2012), dále zamýšlíme navázat představením vzdělávací politiky v Pobaltí (v časopise Orbis scholae 1/2013); proto jsme zvolili pro publikování následující dílčí problematiky tento časopis. Nejprve stručně představujeme Ruskou federaci jako multikulturní zemi, dále se zabýváme národnostní otázkou ve společnosti a ve školním vzdělávání, poté představujeme různé aspekty jazykové politiky. Ve shrnutí ukazujeme hlavní shody a rozdíly mezi Ruskou federací a dříve sledovanými zeměmi v dané problematice.

Školní vzdělávání v Rusku tvoří: (a) počáteční škola, 1.-4. ročník; (b) základní škola, 5.-9. ročník (neúplné střední vzdělání); (c) vyšší ročníky, 10.-11. ročník (úplné střední vzdělání). 
Studii adresujeme především výzkumníkům a odborníkům zabývajícím se srovnávací pedagogikou, vyučujícím a studentům ruského jazyka a představitelům MŠMT ČR.

\section{Ruská federace multikulturní}

Ruskou federaci tvoří 83 rovnoprávných subjektů: 21 republik, 9 krajů, 46 oblastí, 2 města federálního významu, 1 autonomní oblast a 4 autonomní okruhy. Tyto subjekty mají svoji ústavu a zákonodárství (Rossijskaja Fěděracija). K 1. dubnu 2011 činil počet stálého obyvatelstva Ruské federace 142,9 milionu obyvatel (Děmografija). Na území Ruské federace žije více než 160 národností, které mají své mateřské jazyky. Nejpočetnější národností jsou Rusové. Podle sčítání lidu v roce 2010 jich žilo na území Ruské federace 111016 896, tj. cca $81 \%$ obyvatel země. Kromě nich zde žije ještě šest národností s počtem příslušníků větším než jeden milion: Tataři, Ukrajinci, Baškirové, Čuvaši, Čečenci a Arméni (Informacionnyje matěrialy..., rok neuveden).

Převážnou část migračních procesů v Rusku tvoří vnitřní migrace; postupuje ze severu a východu do centra. Vnější migrace činila v roce 2009 pouze $15 \%$ veškeré migrace, avšak právě ona má největší vliv na změnu počtu obyvatel Ruska. 93 \% všech imigrantů v roce 2009 tvořili občané zemí Společenství nezávislých států (SNS), z nichž téměř polovina byli přistěhovalci z Ukrajiny, Uzbekistánu a Kazachstánu (Sovremennaja děmografičeskaja...). Podle údajů Federální migrační služby žilo na území Ruské federace $\mathrm{k} 1$. dubnu 201149300 vynucených přestěhovalců a utečenců; nejvíce v Kazachstánu (20\%), Gruzii (12 \%), Uzbekistánu (5 \%) a Tadžikistánu. Více než 21 \% obyvatel přesídlilo v rámci Ruska z regionů s nestabilní společensko-politickou situací do klidnějších oblastí. Na území Ruska byly více než tři miliony legálních imigrantů. Stálým zdrojem napětí ve společnosti je neregulovanost situace s imigranty za prací, jejichž počet roste (Děmografija; $V$ Rossii ožidajetsja..., 2010). K velkým problémům ruské společnosti patří spory s muslimy. Obavy vyvolávají vztahy mezi národy Ruska a extremistické ideje projevující se mezi mládeží. 


\section{Národnostní otázka ve společnosti a školním vzdělávání}

\subsection{Národnostní politika Ruské federace}

Národnostní politika je v Rusku velmi aktuální. Projevuje se v oblasti řešení národnostních problémů uvnitř Ruské federace a v jejím vztahu k bývalým zemím Sovětského svazu. $\mathrm{V}$ tomto kontextu souvisí také s rolí ruštiny v těchto zemích. Národnostní politika subjektů Ruské federace je pak úzce svázána s otázkou jazykové politiky. Jak konstatuje L. N. Vasiljeva, jazyková politika hraje také významnou roli ve vztazích Ruska k bývalým zemím SSSR, tj. k současným zemím SNS a pobaltským zemím. Autorka upozorňuje na to, že je ohroženo zachování svébytnosti ruského národa $\mathrm{v}$ zahraničí. Významným úkolem je vytvoření systému enkulturace imigrantů do země, zejména pomoc jim při učení se ruskému jazyku a osvojování ruské kultury a při jejich zapojování do života společnosti (Sostojalos ..., 2010).

Ruská federace ratifikovala všechny významné úmluvy upravující postavení národnostních menšin. Všechny její autonomní subjekty schválily v průběhu devadesátých let minulého století vlastní koncepce národnostní politiky (Bahenský, 2003).

V souladu s Ústavou Ruské federace má každý právo definovat a projevovat svoji národnostní př́íslušnost. „Je zakázáno propagovat sociální, rasovou, národnostní, náboženskou nebo jazykovou nadřazenost" (Konstitucija..., 1993). Základním dokumentem vnitřní národnostní politiky je Koncepce státní národnostní politiky Ruské federace. Stanoví cíl zabezpečit jednotu a celistvost Ruska v nových historických podmínkách rozvoje ruské státnosti, soulad celostátních zájmů a zájmů všech jeho národů, rozvoj národních jazyků a kultur a zajištění politické a právní ochrany málopočetných národů a národnostních menšin (Koncepcija..., 1996).

Přijetí Ústavy Ruské federace a řady dohod mezi federálními orgány státní moci a orgány státní moci subjektů RF vedlo k postupnému otupování dřivějšího napětí mezi národy. Stále však přetrvávají jak separatistické, tak i integrační tendence, projevy diskriminace a porušování ústavních práv občanů podle národnostní př́ślušnosti. K základním principům státní národnostní politiky Ruské federace, které uvádí Koncepce státní národnostní politiky Ruské federace, patř́i: (a) rovnost práv a svobod člověka nezávisle na 
jeho rase, národnosti, jazyku, vztahu k náboženství, příslušnosti k sociálním skupinám a společenským sdružením; (b) zákaz jakýchkoli forem omezování práv občanů podle sociální, rasové, jazykové nebo náboženské příslušnosti; (c) právo každého občana určovat a projevovat svoji národnostní příslušnost; (d) rozvoj národních kultur a jazyků národů Ruské federace; (e) zákaz vyvolávání sociálních, rasových, národnostních a náboženských nesvárů, nenávisti nebo nevraživosti; (f) ochrana práv a zájmů občanů Ruské federace za jejími hranicemi, podpora jejích krajanů žijících v zahraničí; (g) uchovávání a rozvoj mateřštiny, kultury a národních tradic; (h) upevňování vztahů občanů Ruské federace s vlastí v souladu s normami mezinárodního práva. Dokument rovněž uvádí, že je třeba vytvářet a implementovat do systému předškolní výchovy, stř̌edního a vysokoškolského vzdělávání a zvyšování kvalifikace programy a kurzy napomáhající výchově kultury komunikace mezi národy, seznamovat děti, mládež a obyvatelstvo s duchovním bohatstvím národů Ruska a vytvářet podmínky pro zachování a rozvoj národní kultury a mateřského jazyka. Národní doktrína vzdělávání v Ruské federaci (na období do roku 2025) uvádí mj., že obyvatelé RF si musí sebe uvědomovat jako nedílnou regionální součást jednotného ruského národa, a to nezávisle na rasové, etnické a náboženské př́slušnosti (Nacionalnaja doktrina..., 2003).

V. V. Romaškin (1999) zdůrazňuje, že bez ohledu na to, že Ústava RF nazývá všechny subjekty rovnoprávnými, mají vlastní ústavy, právo určovat státní jazyky a své občanství pouze republiky. Podobně konstatuje Bahenský (2003), že:

v současné době, stejně jako v minulosti, mají autonomní republiky, okruhy, oblasti a regiony zcela odlišné výsady. [...] Především autonomní republiky a okruhy lze velmi těžko považovat za subjekty, které by měly plně uspokojit „národní cíle“ neruských etnik. [...] Faktem zůstává, že zdánlivě vyřešená národnostní otázka se stala jednou z hlavních př́čin, které vedly k rozpadu tohoto soustátí (SSSR). [...] Nejen Ruská federace jako celek, ale každá autonomní jednotka má větší či menší problémy s řešením vlastní národnostní problematiky, poněvadž každá z nich je multietnická. [...] Ve svobodném Rusku je v oblasti národnostní politiky pravděpodobně nejdůležitějším procesem ona právní harmonizace $s$ okolním světem. Je bez diskuse,že tyto změny neprobíhajílehce, a některézákony garantující práva původních malých národů jsou už při svém vzniku mrtvě narozeným dítětem. Nicméně prostá skutečnost, že je vủbec možné po desetiletích jednat otevřeně v těchto záležitostech, svědčí o zásadním přehodnocení dosavadního př́stupu. 
Autor zdůrazňuje, že většina obyvatel neruského původu má z Rusů ekonomický užitek. Domnívá se, že „větší změny v národnostní politice, postavení, ani ve vlastních potřebách jednotlivých národů však nelze pravděpodobně v blízké budoucnosti očekávat" (Bahenský, 2003).

V roce 1997 podepsaly země Společenství nezávislých států Koncepci formování jednotného vzdělávacího prostoru SNS. Koncepce zakotvuje společné principy státní politiky v oblasti vzdělávání, soulad státních vzdělávacích standardů, programů, kritérií a požadavků na př́ípravu a atestaci vědeckých a vědecko-pedagogických kádrů, stejné možnosti a svobodnou realizaci práv na získání vzdělání ve vzdělávacích zařízeních na území členských zemí SNS. K. A. Pšenko, významný přestavitel Meziparlamentního shromáždění SNS (2006), konstatuje, že při řešení problémů integrace zemí SNS hraje významnou roli vzdělávání, včetně historického. Zdůrazňuje, že na území SNS lze pozorovat rozširrení lživých stereotypů a nesprávných představ o ostatních národech.

V dokumentu z května 2012 O zabezpečení mezinárodního souhlasu je uvedeno, že vláda má zajistit do listopadu 2012 zavedení povinné zkoušky z ruštiny, historie Ruska a základů legislativy RF pro pracující migranty, s výjimkou vysoce kvalifikovaných odborníků (Migrantov zastavjat..., 2012).

\subsection{Národnostní otázka ve školním vzdělávání}

V dokumentu Národní doktrína vzdělávání v Ruské federaci (na období do roku 2025) je zdůrazněn úkol vzdělávacího systému obnovit formy národního a kulturního života mnohonárodnostního Ruska a rozvíjet multikulturní vzdělávání. Multikulturní škola musí odpovídat aktuálním zájmům společenského rozvoje, vycházet ze strategie zachování kulturní různorodosti (Nacionalnaja doktrina..., 2003).

Školský zákon uvádí mj. ustanovení o jednotě kulturního a vzdělávacího prostoru Ruska, principy ochrany a rozvoje národních kultur a regionálních kulturních tradic, které má zajištovat škola (Zakon Rossijskoj Feděracii „Ob obrazovanii“", 1992, 2011).

V dokumentu Koncepce rozvoje multikulturního vzdělávání v Ruské federaci se uvádí, že „vzdělávací systém je hlavní faktor zachování a rozvoje národních kultur a jazyků, skutečný nástroj kulturní a politické integrace ruské společnosti“" (Projekt koncepcii..., 2010). Je zdůrazněn význam celistvého systému inovací multikulturního vzdělávání, respektujícího státní zájmy, 
národní a etnokulturní zvláštnosti obyvatelstva, vytváření harmonie mezi etniky a konfesemi. Koncepce uvádí následující specifické cíle multikulturního vzdělávání:

(a) formování všestranně a harmonicky rozvinuté osobnosti, schopné tvůrčího samostatného rozvoje a uplatňující etnokulturní a občanské sebeuvědomění na základě národní tradice a hodnot ruské a světové kultury; (b) obnova a rozvoj národních kultur a mateřských jazyků národů Ruska jako nezbytných nástrojů socializace dorůstajících pokolení a nejdůležitějšího základu utváření a fungování ruského občanského národa na jeho výchozích úrovních - etnokulturní a národně-územní; (c) formování ruské občanské identity v podmínkách sociálně-politické rozmanitosti regionů $\mathrm{RF}$, multikulturality a multilingvnosti mnohonárodnostního národa Ruska; (d) vytvoření podmínek pro zachování a rozvoj komplementární spolupráce všech etnokulturních skupin v jednotném ekonomickém, sociálním, politickém a kulturním společenství, které se nazývá ruský občanský národ; (e) efektivní příprava absolventů škol a vysokých škol na život v podmínkách federativního státu a současné civilizace, rozš̌řrení možností seberealizace, sociálního růstu a zvyšování kvality života; (f) rozvoj vzdělávacího a odborného potenciálu Ruska, výchova mládeže připravené k odpovědné produktivní intelektuální, organizační a výrobní činnosti v otevřeném multikulturním a multilingvním světě. Dosažení těchto cílů zajištují principy vzdělávací politiky RF.

Nězděmkovskaja (2009) zdůrazňuje roli etnopedagogiky v uchování a reprodukci kultury etnického společenství a jeho etnického sebeuvědomění. Chápe ji jako „interdisciplinární odvětví vědecko-pedagogického poznání, studující národní kulturu a tradiční národní výchovu (národní pedagogiku) s cílem využívat jejich progresivní výchovný potenciál v současné výchově a vzdělávání" (s. 186). Mubinova (2010) konstatuje, že jedním z nejaktuálnějších úkolů ruské pedagogiky, který je předmětem četných diskusí, je harmonická etnonárodnostní výchova. Ruská pedagogika však podle autorky nedospěla za posledních dvacet let $\mathrm{k}$ formulování teoreticky podloženého vymezení její podstaty.

\section{Jazyková politika Ruské federace}

Jak jsme uvedli výše, problematika jazyků v Rusku úzce souvisí s národnostní politikou. Rusko má značný zájem na uchování svých pozic v blízkém zahraničí. Pro první období sovětské moci byla charakteristická snaha vytvořit písemnictví pro jazyky, které ho neměly. $\mathrm{V}$ důsledku toho ovládalo koncem 20. století téměř $90 \%$ neruského obyvatelstva Ruské federace ruštinu. Písemnou podobu má 150 národních jazyků (Rossija, Rossijskaja Feděracija). 


\subsection{Jazyky Ruské federace v legislativě}

Ústava Ruské federace uvádí, že:

(1) Státním jazykem Ruské federace na celém jejím území je ruský jazyk.

(2) Republiky mají právo stanovovat své státní jazyky. V orgánech státní moci, místní samosprávy a ve státních institucích republik se užívají spolu se státním jazykem Ruské federace. (3) Ruská federace zaručuje všem svým národům právo na uchování mateřského jazyka a vytváření podmínek pro jeho učení a rozvoj (Konstitucija..., 1993).

Zákon O jazycích národů Ruské federace konstatuje mj., že:

jazyky národů Ruské federace jsou pod ochranou státu. Stát na celém území Ruské federace napomáhá rozvoji národních jazyků, bilingvismu a mnohojazyčnosti. [...] Ruská federace zaručuje každému právo na užívání mateřského jazyka, svobodnou volbu jazyka komunikace, výchovy, vyučování a tvůrčí činnosti nezávisle na jeho původu, sociální a majetkové situaci, rasové a národní příslušnosti, pohlaví, vzdělání, vztahu k náboženství a bydlišti (Zakon RF ot 25 okt’abrja 1991 g.).

Školský zákon uvádí, že:

občané Ruské federace mají právo získat základní vzdělání ve své mateřštině a zvolit si vyučovací jazyk podle možností, které jim vzdělávací systém nabízí. Právo občanů na získání vzdělání v mateřštině zabezpečuje vytvoření nezbytného počtu příslušných vzdělávacích zařízení, tříd a skupin a podmínek pro jejich fungování. Jazyk (jazyky), v němž probíhá výchova a vyučování ve vzdělávacím zařízení, určuje zřizovatel tohoto zařízení. [...] Ve všech vzdělávacích institucích, které mají státní akreditaci, s výjimkou předškolních, upravují výuku ruskému jazyku jako státnímu jazyku Ruské federace federální státní vzdělávací standardy. Otázky vyučování státním jazykům republik Ruské federace upravuje legislativa těchto republik (Zakon Rossijskoj Feděracii „Ob obrazovanii“, 1992, 2011).

Federální zákon Ruské federace z 1. června 2005 O státním jazyce Ruské federace upravuje užívání státního jazyka RF na jejím celém území a zajištuje práva občanů RF na užívání jejího státního jazyka, na ochranu a rozvoj kultury jazyka a na získání vzdělání v ruštině ve státních a municipálních vzdělávacích zařízeních (Feděralnyj zakon..., 2005).

\subsection{Jazyky ve společnosti}

Jazyková politika Ruska se orientuje na jedné straně na řešení úkolů souvisejících s podporou jeho národních jazyků, na druhé straně na uchování ruštiny v zemích SNS a v pobaltských zemích. 
Od druhé poloviny devadesátých let minulého století se začala uskutečňovat v Ruské federaci souběžně s přestavbou státnosti na nových federativních principech jazyková reforma. Prakticky všechny republiky vyhlásily jako svůj státní jazyk spolu s ruštinou jazyk/y titulní národnosti ${ }^{1}$, což se projevilo ve většině případů $\mathrm{v}$ jejich ústavách a zákonech o jazycích (Romaškin, 1999). Šimonina (2006) konstatuje, že jazyková politika let 1989-1990 se stala katalyzátorem nových tendencí v následujících etnických, jazykových a vzdělávacích procesech. Liferov a Voronova (2009) uvádějí, že v kontextu problémů současného vzdělávání se věnuje otázkám podpory a ochrany ruštiny velká pozornost, a to jak na federální, tak na regionální úrovni. V oblasti fungování ruštiny uvnitř země i za jejími hranicemi existuje řada problémů vyžadujících zvýšené pozornosti ze strany státu a společnosti. V posledních letech z různých politických důvodů došlo k výraznému snížení mezinárodního statusu ruštiny, jejího rozšíření v mezinárodním světě vědy a vzdělávání a v kulturním prostoru.

Významným střediskem výuky ruskému jazyku cizinců i občanů Ruska a vědeckovýzkumné práce v oblasti ruského jazyka je Státní institut ruského jazyka A. S. Puškina. Kromě jiných aktivit organizuje výuku ruskému jazyku cizojazyčných posluchačů $\mathrm{z}$ národnostně-státních útvarů tvořících součást Ruské federace, vypracovává efektivní prostředky výuky ruskému jazyku jako jazyku cizímu a nemateřskému a podporuje studium ruského jazyka a kultury v zahraničí (Gosudarstvennyj institut...).

\subsection{Jazyky ve školním kurikulu}

V současné době se vyskytuje ve všeobecně vzdělávacích školách Ruské federace ve výuce humanitním předmětům celkem 28 autochtonních jazyků národů Ruska (bez jejich různých subvariant). Z nich je užíváno 16 jako vyučovací jazyky na počátečním stupni vyučování, další dva jazyky na stupni základního všeobecného vzdělávánía dalších 10 na stupnistředního (úplného) vzdělávání. Výuka všem humanitním předmětům probíhá také v jazycích

Titulní jazyk je jazyk konkrétního etnika, tvořícího v dané době a na daném území stát nebo jiný administrativně-státní útvar. Nemusí být nutně jazykem státním. (Např́klad Dagestán má několik státních jazyků, žádný z nich však podle neodpovídá názvu státu.) Ruština je titulním jazykem v Ruské federaci a netitulním v jejích všech ostatních národnostně-státních nebo národnostně-územních útvarech. Termín ne/titulní se užívá také ve spojení etnikum, národ (Slovo «titulnyj»). Své názvy (titul) získaly tyto subjekty zpravidla od jména národa, který na jejich území žije od pradávna. Proto se nazývají tyto národy „titulní“ (Romaškin, 1999). 
některých národnostních menšin, např. $\mathrm{v}$ arménštině, azerbajdžánštině, gruzínštině, kazaštině, estonštině, polštině nebo němčině. 43 mateřských jazyků je vyučováno jako vyučovací předměty, a to od 1. do 9. ročníku, ojediněle až do 11 . ročníku. Ve vzdělávacím systému RF tak lze napočítat ve vyučovacím procesu v obou formách (vyučovací jazyk a vyučovací předmět) jazyky 71 národností. Zvýšení podílu mateřštiny a statusu jazyků republik na úroveň státních jazyků oslabilo pozici ruštiny, která se začala vyučovat v řadě subjektů RF jako státní jazyk RF v počtu 3 hodiny týdně. Ke změnám došlo i ve školách s mateřským (neruským) vyučovacím jazykem, kde vyučování $\mathrm{v}$ mateřštině se začalo realizovat plně do 11 . ročníku včetně (a dokonce přešlo i na vysoké školy). Takové tendence v ruském systému všeobecného vzdělávání vedou objektivně k poklesu dvojjazyčnosti, k oslabování role ruštiny (Kuzmin \& Artěmenko, 2007). Autoři upozorňují, že to vše je v přímém rozporu s jedním ze základních principů Evropské charty regionálních nebo menšinových jazyků, podle něhož se nesmí dít ochrana a rozvoj těchto jazyků na úkor oficiálních jazyků a nezbytnosti jejich výuky.

V souladu se školským zákonem probíhá vyučování, příprava a zvyšování kvalifikace cizinců ve vzdělávacích zařízeních $\mathrm{RF}$, stejně jako jejích občanů v zahraničních institucích, na základě přímých dohod, uzavíraných mezi vzdělávacími zařízeními, asociacemi, řídicími orgány v oblasti vzdělávání, dalšími právnickými osobami i fyzickými osobami v souladu s mezinárodními dohodami RF (Zakon Rossijskoj Feděracii „Ob obrazovanii“, 1992, 2011).

V dokumentu Návrh koncepce rozvoje multikulturního vzdělávání v Ruské federaci se uvádí, že plurilingvní vzdělávací model multikulturního vzdělávání spojuje uchování stabilních vzdělávacích funkcí mateřských jazyků národů Ruska a posílení role ruštiny, která se stává aktivním zprostředkovatelem a skutečným katalyzátorem dialogu kultur. Hlavní role ruštiny v ruském vzdělávacím prostoru, ve společensko-politickém, hospodářském a duchovním životě federativního státu předurčuje její prioritní postavení jako jazyka vyučování a učení, stabilního principu fungování systému multikulturního vzdělávání (Projekt koncepcii...).

Šimonina (2006) konstatuje, že jazyková reforma z let 1989-1990 kladla důraz na zahrnutí národnostně-regionální komponenty do obsahu vzdělávání. Hlavním cílem mělo být vychovat člověka v duchu národní kultury a rodného jazyka a jejich základům ho naučit. $V$ rámci reformování ruského vzdělávání $\mathrm{v}$ devadesátých letech minulého století byla dokončena koncepce vyučování 
na principu funkčního bilingvismu. Spočívá v prioritě mateřského jazyka a možnosti doplňovat jazyky další. Funkční bilingvismus v praxi znamená vyučování $v$ téže etapě vzdělávání části předmětů v mateřském (neruském) jazyce a části předmětů v ruštině a diferenciaci cílů vyučování v závislosti na individuálních požadavcích žáků. Princip dvojjazyčnosti nebo vícejazyčnosti je realizován ve většině republik RF. Sít národních škol ${ }^{2}$ se nachází především v národních republikách a dalších subjektech s etnicky neruským nebo silně smíšeným obyvatelstvem, např. v moskevské aglomeraci. Školy s neruským vyučovacím jazykem (tj. jazykem národností žijících na území RF) se nazývají nově školy s etnokulturně-regionální variantou (pro jednu etnonárodnostní skupinu) - ruština je v těchto školách povinný předmět. Schmidt (2010) uvádí, že ve vzdělávací politice se upozorňuje stále častěji na problematiku nedostatečného ruskojazyčného vzdělávání žáků v národních školách z rodin, v nichž se hovoří mateřštinou (ne ruštinou) nebo dvojjazyčně.

Podle charakteru organizace vyučovacího procesu na dvojjazyčném základělze v současné době vydělit, v souladu s klasifikací Institutu národních problémů vzdělávání, několik samostatných škol tohoto typu:

Model 1. Národní škola s vyučováním v mateřském jazyce od 1. do 11. ročníku. Ruština se vyučuje pouze jako předmět (Tatarstán, Baškortostán, SachaJakutsko, částečně Tuva).

Model 2a. Národní škola s výukou v mateřštině do 7. nebo 9. ročníku (ruština jako vyučovací předmět), s další výukou v ruštině ve vyšších ročnících (vesnické školy Tuvy, Burjatsko, Čuvašsko, školy v řadě teritorií Severního Kavkazu, městské školy v Tatarsku a Baškirsku).

Model 2b. Národní škola s výukou v mateřštině do 4. ročníku (ruština jako vyučovací předmět), $s$ dalším přechodem výuky na ruštinu (městské školy Tuvy, Kalmykije, Adygeje, Osetijae, Čuvašije, Mordovije aj.).

Model 3a. Národní škola s výukou v ruštině od 1. do 11. ročníku a s (rozšířenou) výukou mateřskému jazyku a kultuře (Karélie, Mordovije, Komi, školy Severu, Sibiře, Dálného východu aj.).

2 V roce 1918 vznikl jako součást všeobecně vzdělávacích škol typ škol s mateřským jazykem jako jazykem vyučovacím nebo vyučovacím předmětem a s prvky národní kultury v obsahu vzdělávání. Později byl nazván národní (národnostní) škola (национальная школа). V průběhu let si však národní škola zachovala pouze jeden rys národní př́slušnosti, a to vyučování ruštině (Dvujazyčnoje obrazovanije, 1999). 
Model 3b. Národní škola s výukou v mateřštině v 1. a 2. ročníku, připravující $\mathrm{k}$ následnému přechodu na ruštinu jako vyučovací jazyk (kočovná škola podmínkách za polárním kruhem, rodinné kočovné školy Jamalo-Něněckého okruhu a dalších jednotlivých území).

Jednotlivé modely tvoří ruská škola jako národní a škola diaspory, kde probíhá výuka představitelů různých etnik mimo území, kde tato etnika žijí, a představuje rovněž zvláštní typ dvojjazyčného a bikulturního vzdělávání.

Vznik různých typů národních škol z hlediska organizace dvojjazyčného vyučování podmínil velký počet faktorů - interních i mimoškolních. Proto také úroveň znalosti ruštiny u žáků neruských škol závisí nejen na typu národní školy, ale také na konkrétní jazykové situaci v daném regionu, kulturněhistorických tradicích, individuální motivaci učit se tomuto jazyku, vztahu rodičů a starších př́ibuzných k volbě vyučovacího jazyka a na prospěchu dětí (Dvujazyčnoje obrazovanije, 1999).

Učební plány zajištují na základě hlavních dokumentů Ruské federace o vzdělávání (včetně Ústavy $R F$ ) možnost vyučování ve státních jazycích subjektů $\mathrm{RF}$ a $\mathrm{v}$ mateřském (neruském) jazyce a možnost stanovovat počet vyučovacích hodin určených na výuku těmto jazykům (Feděralnyj gosudarstvennyj..., 2009). Ve Federálním základním učebním plánu pro počáteční všeobecné a základní všeobecné vzdělávání jsou uvedeny pro vzdělávací zařízení s ruským a mateřským (neruským) vyučovacím jazykem vzorové učební plány s týdenním rozvrhem vyučovacích hodin. Počet hodin určených na výuku vyučovacímu předmětu Mateřský (neruský) jazyk a literatura ve školách s ruským (nemateřským) a mateřským (neruským) vyučovacím jazykem stanoví př́ílušný subjekt Ruské federace a/nebo škola. Vyučovací předmět Cizí jazyk se vyučuje od 2. ročníku, byl zvýšen počet hodin určených pro jeho výuku (od 2. do 9. ročníku šest hodin týdně). Ve vzdělávacích zařízeních s ruským (nemateřským) vyučovacím jazykem se doporučuje využívat disponibilní časovou dotaci pro vyučování předmětu Mateřský (neruský) jazyk a literatura (Feděralnyj bazisnyj učebnyj plan ...). V souladu s Federálním státním standardem počátečního všeobecného vzdělávání tvoří předmětovou oblast Filologie předměty ruský jazyk, mateřský jazyk; literární čtení, literární čtení v mateřštině; cizí jazyk. $\mathrm{V}$ předmětu cizí jazyk si žáci musí, kromě rozvinutí základních řečových dovedností, „vytvořit přátelský vztah a tolerantní postoj k nositelům jiného jazyka na základě obeznámení se s životem svých vrstevníků z jiných zemí, s dětským folklorem a dostupnými 
příklady z dětské krásné literatury“ (Feděralnyj gosudarstvennyj..., 2009). Federální státní vzdělávací standard všeobecného vzdělávání. Střední (úplné) všeobecné vzdělávání uvádí mj., že:

standard umožňuje respektovat regionální, národ/nost/ní a etnokulturní zvláštnosti národů Ruské federace. Je zaměřen na formování ruské občanské identity žáků, zabezpečení jednoty vzdělávacího prostoru Ruské federace, zachování a rozvoj kulturní mnohotvárnosti a jazykového dědictví mnohonárodnostního národa Ruské federace, realizaci práva na učení se mateřskému jazyku, osvojení si duchovních hodnot a kultury mnohonárodnostního národa Ruska. (Feděralnyj gosudarstvennyj ..., 2011)

Úkolem předmětové oblasti Filologie a cizí jazyky je mj. „vytvořit představy o roli jazyka a životě člověka, společnosti a státu; seznámit se prostřednictvím ruského a mateřského (neruského) jazyka, cizího jazyka a literatury s hodnotami národní a světové kultury" (tamtéž).

\section{Shrnutí}

V následujícím shrnutí vycházíme ze shrnutí stati Multikulturalita Německa, Velké Británie, Švédska a České republiky a opatření vzdělávací politiky pro školní vzdělávání, uveřejněné v časopise Orbis scholae (Ježková, 2010). Podle možnosti doplňujeme komparaci se situací v Rusku. Dbáme na to, abychom neporovnávali „za každou cenu“, a tedy nesrovnávali „nesrovnatelné s nesrovnatelným", nebot’ vzhledem ke zcela odlišnému historickému vývoji Ruska je současná situace $\mathrm{v}$ něm $\mathrm{v}$ mnohém od ostatních námi sledovaných zemí zcela odlišná.

Mezi sledovanými zeměmi jsme zaznamenali následující hlavní shody a rozdíly: (1) Všechny země se stávají vlivem přílivu imigrantů stále více multikulturními. Př́liv imigrantů do České republiky začal ze známých společenskopolitických důvodů později než do Německa, Velké Británie a Švédska.VRuskujde především o migraci vnitřní,tj.v rámci subjektů RF, země je multikulturní „sama o sobě“ díky svému historickému vývoji. (2) Všechny sledované země ratifikovaly Chartu regionálních nebo menšinových jazykü. Rusko se připojilo v roce 2001 k zemím, které Chartu podepsaly, dosud ji však neratifikovalo. (3) Ve Velké Británii, Švédsku i České republice je součástí kurikula multikulturní výchova/vzdělávání, v Rusku není, pouze se hovoří o jejím významu. $V$ počáteční a základní škole je vyučován předmět 
Základy duchovně-mravní kultury národů Ruska. Ve střední škole nalézáme prvky multikulturní výchovy v integrovaném předmětu Společenské vědy, $\mathrm{v}$ části Rusko ve světě. (4) Opatření vzdělávací politiky jsou zaměřena ve všech sledovaných zemích převážně na imigranty, v Rusku na jeho národy. (5) Hlavním prostředkem integrace imigrantů do školy a společnosti je podpora znalosti většinového jazyka země. Významnou roli hraje $v$ této souvislostipř́prava dětínaškolua primárnívzdělávání.VRuskunepředstavuje vnější imigrace závažný problém. (6) V Německu se projevuje vliv sociálněekonomického zázemí žáků na jejich úspěšnost ve škole nejvíce u imigrantů, ve Velké Británii u určitých skupin autochtonního obyvatelstva. V Rusku jde především o problém sociálního vyloučení, znamenajícího omezení přístupu některých skupin žáků ke vzdělávání (v závislosti na místu bydliště - místa značně vzdálená od vzdělávacích zařízení, na věku a na zdravotním stavu). (7) V Německu a v České republice nepředstavuje vzdělávání autochtonních menšin v kontextu vzdělávací politiky významný problém, ve Velké Británii a Švédsku je toto téma aktuální, stejně tak v Rusku. (8) Všechny sledované země i Rusko podporují rozvoj mateřského jazyka autochtonních menšin. V Rusku jde na jedné straně o podporu menšinových národních jazyků, na druhé straně o snahu bránit poklesu role ruštiny v celé zemi i za jejími hranicemi. (9) Jednou z forem jazykové podpory dětí v osvojování druhého jazyka je CLIL (Content and language integrated learning). Ve Velké Británii (Walesu, Severním Irsku a Skotsku) se týká především autochtonního obyvatelstva, ve Švédsku a částečně v Německu imigrantů; v Anglii a České republice se týká pouze, v Německu především, výuky cizím jazykům. V ruských kurikulárních dokumentech ani v odborných statích jsme se s daným pojmem nesetkali. Domníváme se, že do určité míry odpovídá tomuto termínu termín funkční bilingvismus, o němž se zmiňujeme v textu.

Celkově můžeme konstatovat, že až na výjimky nejsou mezi původními třemi sledovanými zeměmi a Českou republikou zásadní rozdíly; situace v Rusku je více specifická. Uvědomujeme si, že vzhledem k tomu, že ve své stati vycházíme převážně z oficiálních dokumentů, charakterizujeme zvolenou problematiku spíše na úrovni Soll, zatímco rovina Ist může být v mnohém jiná. 


\section{Literatura}

Bahenský, F. (2003). Národnostní politika v Ruské federaci v 90. letech 20. století. Dostupné z http://www.nkp.cz/seminar/npol.htm\#FB

Děmografija. (Rok neuveden). Dostupné z http://www.gks.ru/bgd/free/b11_00/IssWWW.exe/ Stg/dk04/8-0.htm

Dvujazyčnoje obrazovanije v školach Rossijskoj Feděracii. (1999). Dostupné z http://zapravakbr. $\mathrm{ru} /$ newfile_33.htm

Feděralnyj bazisnyj učebnyj plan i primernyje učebnyje plany dlja obrazovatělnych učrežděnij Rossijskoj Feděracii, realizujuščich programmy obščego obrazovanija. Načalnoje obščeje i osnovnoje obščeje obrazovanije. Sredněje (polnoje) obščeje obrazovanije. (2004). Moskva: Ministěrstvo obrazovanija i nauki Rossijskoj Feděracii. Dostupné z http://window.edu.ru/ window/library?p_rid=39309

Feděralnyj gosudarstvennyj obrazovatělnyj standart načalnogo obščego obrazovanija. (2009). Moskva: Ministěrstvo obrazovanija i nauki Rossijskoj Feděracii. Dostupné z http://mon. gov.ru/files/materials/7195/373.pdf

Feděralnyj gosudarstvennyj obrazovatělnyj standart obščego obrazovanija. Sredněje (polnoje) obščeje obrazovanije. (2011). Moskva: Ministěrstvo obrazovanija i nauki Rossijskoj Feděracii. Dostupné z http://standart.edu.ru/catalog.aspx?CatalogId=6408

Feděralnyj zakon Rossijskoj Feděracii ot 1 ijuňa 2005g. N 53-F3 O gosudarstvennom jazyke Rossijskoj Feděracii. Dostupné z http://www.rg.ru/printable/2005/06/07/yazyk-dok. html

Gosudarstvennyj institut russkogo jazyka imeni A. S. Puškina. (Rok neuveden). Dostupné z http:// www.pushkin.edu.ru/index.php?m=070101

Informacionnyje matěrialy ob okončatělnych itogach Vserossijskoj perepisi naselenija 2010 goda. Nacionalnyj sostav naseleniaj Rossijskoj Feděracii. Feděralnaja služba gosudarstvennoj statistiki. (Rok neuveden). Dostupné z http://www.gks.ru/free_doc/new_site/perepis 2010/perepis_itogi1612.htm

Ježková, V. (2010). Multikulturalita Německa, Velké Británie, Švédska a České republiky a opatření vzdělávací politiky pro školní vzdělávání. Orbis scholae, 4(3), 111-124.

Ježková, V. (2012). Reforma školního vzdělávání v Rusku. Orbis scholae, 6(1), 95-106.

Koncepcija gosudarstvennoj nacionalnoj politiki Rossijskoj Feděracii. (Utveržděna Ukazom Preziděnta Rossijskoj Feděracii ot 15 ijuňa 1996 g. No 909). Dostupné z http://www.scrf.gov. $\mathrm{ru} /$ documents/27.html

Konstitucija Rossijskoj Feděracii (priňata na vsenarodnom golosovanii 12 děkabrja 1993 g.) (s popravkami). Dostupné z http://constitution.garant.ru/

Kuzmin, M. N., \& Artěmenko, O. I. (2007). Spravka o jazykach narodov Rossijskoj Feděracii $i$ o jazykach, $v$ otnošenii kotorych $v$ Rossii možet primeňat'sja Jevropejskaja chartija regionalnych jazykov ili jazykov meňšinstv ot 5 nojabrja 1992g. Moskva: INPO. Dostupné z http://inpo-rus.ru/8/

Liferov, A. P., \& Voronova, O. J. (2009). Russkij jazyk v paradigme sovremennogo obrazovanija: sociokulturnyj i geopolitičeskij aspekty. Pedagogika, 73(2), 3-11.

Migrantov zastavjat sdat' ekzameny po russkomu jazyku. (7 maja 2012 g.). Dostupné z http:// www.bbc.co.uk/russian/society/2012/05/120507_putin_migrants_decree.shtml 
Mubinova, Z. F. (2010). Etnonacionalnoje vospitanije v obščeobrazovatělnoj škole. Čelovek i obrazovanije, 23(2), 46-51.

Nacionalnaja doktrina obrazovanija v Rossijskoj Feděracii. (25.11.2003). Dostupné z http:// www.humanities.edu.ru/db/msg/46741

Nězděmkovskaja, G. V. (2009). Stanovlenije etnopedagogiki v Rossii. Čelovek i obrazovanije, 22(7), 7-26.

Projekt koncepcii razvitija polikulturnogo obrazovanija v Rossijskoj Feděracii. (2010). Dostupné z http://mon.gov.ru/work/vosp/dok/6988/

Pšenko, K. A. (2006). Istoričeskij faktor v stanovlenii i razvitii Sodružestva Nězavisimych Gosudarstv. Čelovek i obrazovanije, 19(7), 23-27.

Romaškin, V. V. (1999). Jazykovaja reforma v Rossijskoj Feděracii. In Altaj i Centralnaja Atika: kulturno-istoričeskaja prejemstvennost' - Gorno-Altajsk (pp. 29-38). Dostupné z http:// www.philology.ru/linguistics2/romashkin-99.htm

Rossija, Rossijskaja Feděracija. Dostupné z http://www.russiafederation.ru/

Schmidt, G. (2010). Russische Föderation. In H. Döbert, W. Hörner, B., von Kopp, \& R. Reurter (Hrsg.), Die Bildungssysteme Europas (pp. 619-643). Baltmannsweiler: Schneider-Verlag Hohengören.

Slovo «titulnyj». Dostupné z http://zhivoeslovo.ru/index.php?option=com_content\&task=view \&id=1158\&Itemid=122

Sostojalos očerednoje zasedanije Mežreligioznogo soveta Rossii. Dostupné z http://www.regions. $\mathrm{ru} / \mathrm{news} /$ national/2330326/

Sovremennaja děmografičeskaja situacija v Rossijskoj Feděracii. Dostupné z http://www.gks.ru/ wps/wcm/connect/rosstat/rosstatsite/main/population/demography/\#

Šimonina, N. V. (2006). Nacionalno-russkoje dvujazyčnoje obščeje sredněje obrazovanije $v$ polikulturnom Severo-Kavkazskom regioně. (Dissertacionnaja rabota). Pjatigorsk, RU. Dostupné z http://www.lib.ua-ru.net/diss/cont/219196.html

Vasiljeva, L. N. (Rok neuveden). Sochraněnije pozicij russkogo jazyka kak faktor obespečenija nacionalnoj bezopasnosti Rossijskoj Feděracii. Dostupné z http://www.budzhet.lawmix. $\mathrm{ru} / \mathrm{comm} / 9090 /$

V Rossii ožidajetsja pritok kvalificirovannych migrantov. (30.12.2010). Dostupné z http://www. regions.ru/news/migration/2332692/

Zakon RF ot 10.07.92 N 3266-I (red. Ot 03. 12. 2011) „Ob obrazovanii“. Dostupné z http://www. zakonprost.ru/zakony/ob-obrazovanii/

Zakon Rossijskoj Feděracii «Ob obrazovanii» ot 10 ilulja 1992 g. N 3266-1. Dostupné z http://mon. gov.ru/dok/fz/obr/3986/

Zakon RF ot 25 oktáarja 1991g. N 1807-I „O jazykach narodov Rossijskoj Feděracii“ (v red. Feděralnych zakonov ot 24.07.1998 N 126-F3, ot 11.12.2002 N 165-F3). Dostupné z http:// www.internet-law.ru/law/smi/iazyk.htm

\section{Autorka}

PaedDr. Věra Ježková, Ph.D., Univerzita Karlova, Pedagogická fakulta, Ústav výzkumu a rozvoje vzdělávání, Myslíkova 7, 11000 Praha 1, e-mail: vera.jezkova@pedf.cuni.cz 


\title{
Multiculturalism of the Russian Federation and its reflection in school education
}

\begin{abstract}
The Russian Federation is a considerably multicultural country, which also influences the school. The subjects of the study are two main areas: dealing with the nationalities issue and the language policy of the Russian Federation, namely at the level of the whole society and at the level of school education. In the summary the situation in the Russian Federation is compared to the situation in the Czech Republic and and other countries: Germany, Great Britain and Sweden.
\end{abstract}

Keywords: multiculturalism, language policy, curriculum, Russian Federation

\section{Studia paedagogica $1 / 2012$}

První letošní číslo časopisu Studia paedagogica je věnováno vzdělávání dospělých a obsahuje následující studie: Celoživotní učení a chut' se učit (Theo Van Dellen), Tři inspirace od Petera Jarvise (Jan Nehyba), Teorie transformativního učení(se) dospělých (Miroslava Dvořáková), Vzdělání dospělých mezi profesionalizací a profesionalismem (Miomir Despotović), Jaké kompetence mají mít vzdělávatelé dospělých? (Aleksandra Pejatović), Konceptualizace profesionality u vzdělavatelů dospělých (Marcella Milana, Oleksandra Skrypnyk), Úvahy o profesionalitě vzdělavatelů dospělých (Linda Evans), (Ne)účast dospělých ve vzdělávání jako výsledek individuálních strategií sociálně zakotvených jednotlivců (Martin Kopecký), Mezigenerační učení: učit se mezi sebou v rodině (Milada Rabušičová, Lenka Kamanová, Kateřina Pevná), Postoje zdravotních sester k neformálnímu profesnímu vzdělávání (Jana Havlíčková).

http://www.phil.muni.cz/journals/index.php/studia-paedagogica

Průcha J., \& Veteška J. (2012). Andragogický slovník. Praha: Grada.

Jedná se o první slovník andragogiky, vzdělávání a rozvoje lidských zdrojů na českém knižním trhu. Zabývá se teorií, výzkumem a praxí vzdělávání dospělých, rozebírá různé formy profesního vzdělávání, podnikového vzdělávání, zájmového a občanského vzdělávání. Věnuje se androdidaktice, psychologickým a sociálním aspektům učení a vzdělávání dospělých a přináší reálie (andragogické instituce, časopisy, pracoviště, publikace aj..). Slovník je určen odborníkủm působícím v oblasti vzdělávání dospělých, pedagogům a manažerům vzdělávání, personalistům, pracovníkům z útvarů rozvoje a řízení lidských zdrojů, studentům a doktorandům těchto oborů, vzdělávacím politikům, sociologům i široké veřejnosti. 